\title{
Population Ecology and Economic Importance of Calotropis procera as an Exotic Medicinal Plant
}

\section{Moustafa ARA*, Sarah SQ}

Botany Department, Faculty of Science, Suez Canal University, Ismailia, Egypt

*Corresponding author: Abdel Raouf A Moustafa, Botany Department, Faculty of Science, Suez Canal University, Ismailia, Egypt, E-mail: raoufmoustafa2@hotmail.com

\section{Review Article \\ Volume 1 Issue 1}

Received Date: May 23, 2017

Published Date: June 15, 2017

DOI: $10.23880 /$ jenr- 16000105

\section{Abstract}

A review is given regarding the medicinal plant Calotropis procera (Aiton) W.T a member of the family (Asclepiadaceae) commonly known as Giant Milk weed. It demonstrated that Calotropis is a perennial xerophytic woody shrub that has a great capacity to inhabit abandoned lands, it tolerated poor soils with limited nutrition and moisture, known to establish an intensive root system as a drought resistance mechanism. It exhibited allelopathic properties and phytoremediation, considered invasive in many habitats.

C. procera is widespread in tropical and subtropical regions of the globe, in Egypt it's distributed through several phytogeographic regions with different edaphic properties, consequently, it showed great polymorphism and wide variety in metabolites in accordance to different environments. The seeds possess a unique silk formation that aided in dispersal through wind, water or any moving substance.

Environmental conditions specially precipitation rates, was found to control the invasive behavior of the species since it showed no invasive attribute in arid environments where it's originally found such as Egypt or Saudi Arabia, on the contrary, Australia for instance knew C. procera as an invasive naturalized plant.

A great benefit could be taken from Calotropis procera on many levels, as on one hand it is known traditionally, in folk medicine to have purgative and anthelimintic properties and used in treating leprosy, ulcers, tumors and piles as well as purgative, anticoagulant, and anticancer, moreover, the plant's latex has been known for cardiac glycoside content and contains compounds with pesticide properties, while on the other hand, its biomass proved a tendency to be a good source of renewable energy and hydrocarbon. Finally, Calotropis procera populations have an immense ecologic role being habitat for several organisms, displaying phytoremedy properties in contaminated soils and its ability to rehabilitate deserted land bringing back life once again.

Keywords: Renewable energy; Bioremediation; Allelopathy; Pesticide; Invasives; Cardiac glycosides; Uscharin 


\section{Journal of Ecology \& Natural Resources}

\section{Introduction}

Medicinal plants provide a major cultural and biological weight to humanity. They serve as food source, flavoring spices, means of remediation, energy source and national income [1]. The use of medicinal plants in drug manufacture has become a global trend in the last two decades [2]. Farnsworth and Soejarto; Schippmann, et al. [3-4] have estimated the plants used medicinally worldwide of more than 53000 species.

The plant family Asclepiadaceae includes more than 2,000 species classified under 280 genera are distributed worldwide in the tropical and sub-tropical regions [5]. As a family member, Calotropis procera has captured the attention since on one hand, it has a great value as a medicinal plant with notable importance in folk medicine (Boulos) [6], its cardiac glycoside content and the ability to act as a pesticide [7-10]. On the other hand, researches have discussed its potential to be source of renewable energy and hydrocarbon $[11,12]$.

The plant is a perennial xerophytic woody shrub which is able to thrive in harsh conditions of heat, drought and poor soils $[13,14]$. It's characterized with a unique seed structure that counts primarily for its great dispersal capability. C. procera is widespread in tropical and subtropical regions of the globe, in Egypt its distributed through several phytogeographic regions, and is spreading further to inhabit new ecosystems $[15,16]$.

Calotropis procera has significant morphological plasticity enables it to thrive harsh conditions of drought, salinity and waterlogging $[17,18]$. As well as wide range of temperatures and urban stress. It reproduces by seeds and vegetative propagation as well $[19,14]$.
The significant dispersal of Calotropis procera, along with its high adaptability to severe environments, has driven researchers to consider its invading abilities, it even suffers widespread cutting in several regions as an invasion control strategy [20]. However, the numerous benefits and outcomes from using the plant in industrial and therapeutic aspects could possibly overcome the invasion concerns. In Egypt, even though being widespread, C. procera populations didn't exhibit invasive behavior yet. This review aims at assessing the Calotropis procera (Aiton) population in Egypt, discussing its distribution, population dynamics and dispersal behavior with respect to its ecologialc role and potential economic importance.

\section{Geographic Distribution}

Calotropis procera (Aiton) W.T a member of the family (Asclepiadaceae), Asclepias procera Aiton is the most common synonym for it (Boulos) [21]. Calotropis procera is widely distributed around the globe and hence it has several common names, it is known in Arabic as Ushar or Oshar [22,23]. While in English it's Giant milk weed, Sodom apple, calotrope, Frensh cotton, in French it's Bois canon or Arbre de soie, it's Algodón de seda in Spanish [24], cabbage tree, rubber bush and rubber tree [14].

It is native to tropical and subtropical Africa, (Somalia, Egypt, Libya, south Algeria, Morocco, Mauritania and Senegal), Madagascar, Asia (India, Pakistan, Afghanistan, Iran, Arabia and Jordan), Southern Asia, and Indochina to Malaysia [25,13]. The plant has been naturalized in Australia, Central and South America, the Caribbean islands, Indonesia, and many Pacific islands [13], (Figure 1).

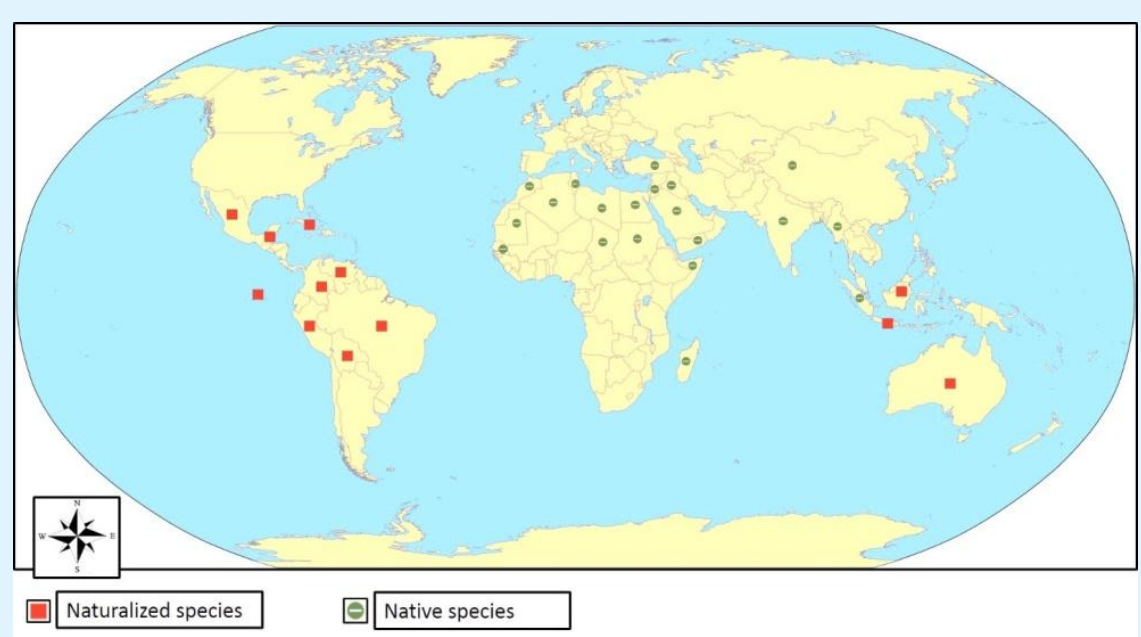

Figure 1: Global distribution of Calotropis procera in both native and naturalized habitats. 


\section{Journal of Ecology \& Natural Resources}

In Egypt, urban areas of Helwan, South Cairo Province [26], Aswan, Nile river islands and its sandy bank, New Valley (El-Kharga oases, Cairo-Suez road from, the Galala desert, the northern province of the desert east of the Nile, Wady Feran, (Saint Catherine mountain area), Nuweibaa from, Aqaba Gulf sector of the Red Sea coastal plains; and Arish, the Mediterranean coastal land [15], El Maghara, from Northern anticlines of Sinai; Shalateen, from Gebel Elba district at the South-East Eastern Desert on the Red Sea, (Figure 2).

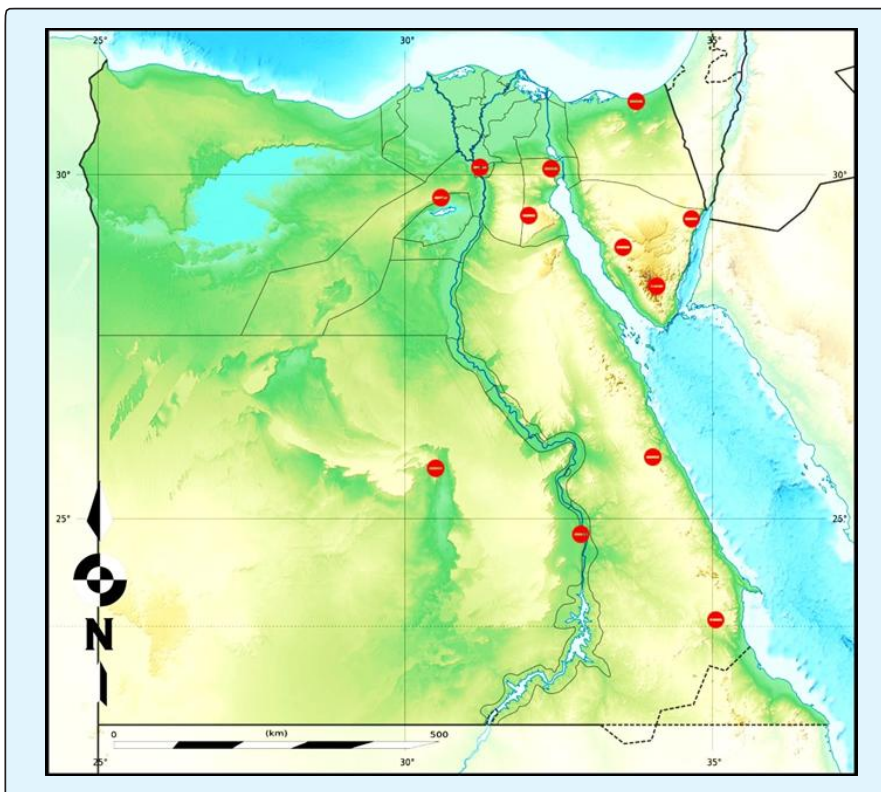

Figure 2: Distribution of Calotropis procera in Egypt.

\section{Morphology}

Calotropis procera is a single or multiple stemmed shrub of 2-6-meter height [23-28] stems are grayishgreen in color, smooth in texture (Figure 3 ).

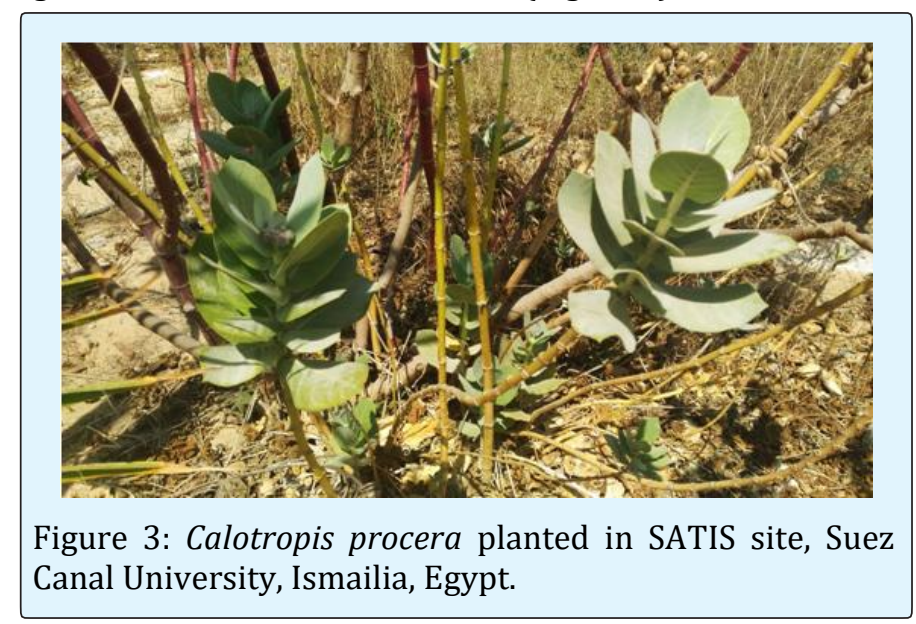

Mature stems have a deeply fissured, cork-like bark that is light brown in color [13-21]. The leaves are simple, sub-sessile, opposite decussate, slightly thick or fleshy, oblong, obovate to nearly orbicular, short-pointed to blunt at the apex and have a clasping heart shaped base (Figure 4).

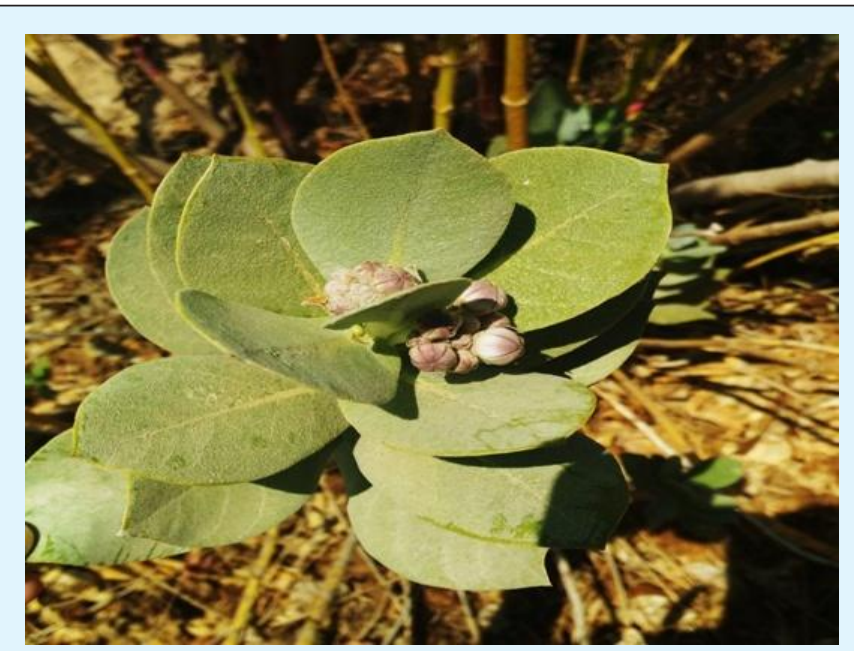

Figure 4: Calotropis procera flowers and leaves.

The leaf blades are light to dark green with nearly white veins, slightly leathery, and have a fine coat of soft hairs that rub-off. Leaves are pubescent when young and glabrous on both sides on maturity. They have a waxy appearance and contain a white milky sap $[29,30]$. Leaves are large up to $15 \mathrm{~cm}$ long and $10 \mathrm{~cm}$ broad, with no leaf stalk [31].

The flowers are regular, bisexual with a faint odor, they are borne in clusters of ovoid flower buds in the forks of the uppermost leaves each cluster contains 3-15 flowers. The clusters are surrounded by involucres of several small oblong, pointed scaly caduceus bracts. The main stalk of these flower clusters (i.e., peduncle) is $20-55 \mathrm{~mm}$ long, and each flower has a stalk (i.e., pedicel) about 15$25 \mathrm{~mm}$ long. Calyx and corolla are 5-lobed; sepals 7-8 $\mathrm{mm}$ long; ovate acute, hairy outside; while petals $2-3 \mathrm{~cm}$ wide, white with purple tips internally; fruit ovoid, inflated, 8$12 \mathrm{~cm}$ long [13]. Flowers have crown-like center [31,21].

The fruits are follicle (8-14 9 6-9 $\mathrm{cm})$, sub-globose to obliquely ovoid. Its apex is rounded, green, spongy, and smooth-that split and invert when mature to release seeds [30,32]. Seeds are numerous (350-500 per fruit), flat, obovate, $695 \mathrm{~mm}$, with silky white pappus of $3 \mathrm{~cm}$ or longer [23]. 


\section{Journal of Ecology \& Natural Resources}

\section{Ecology}

Calotropis procera is a soft-wooded, evergreen, perennial shrub that forms mono-specific stands without or with few associated weeds such as Alhagi graecorum, Convolvulus arvensis, Solanum nigrum and Cynodon dactylon [33]. It is highly resistant to drought, it thrives in soils ranging from alkaline to saline [30,33], it was found inhabiting waste rock dumps, tailings storage facility, and evaporation ponds [34], as well as, along roadsides, watercourses, river flats and coastal dunes, it is often prevalent in disturbed areas $[13,35,23]$.

The plant is known generally to tolerate habitats with annual precipitation of $150-1,000 \mathrm{~mm}$ per year and temperature range of $20-30^{\circ} \mathrm{C}$ (CABI 2005), however in Egypt it survived on precipitation rate of only $4.7 \mathrm{~mm}$ per year and temperature as low as $13.4^{\circ} \mathrm{C}$ [36]. As a result, Calotropis procera was found to produce deep roots and root suckers, and rarely grows in shallow soils over unfractured rock [34].

According to Ibrahim (2013), the effect of water deficit, water logging and salinity stresses were applied on C. procera to study its resistance capacity, as a result, the plant have reduced photosynthetic pigments significantly through leave shedding, while in contrast, the shoot/root ratio were remarkably increased, presumably leave shedding could reduce organs that are no longer in use and increases photosynthetic efficiency per unit area of land [37], besides it minimizes water loss and transpiration during the dry season [38]. In the meantime, increasing root system ensures reaching water and nutrient in far depths beyond the dry surface. Furthermore, C. procera tend to form small size populations in highly saline soils, and consequently high levels of Na were found in its leaves to cope with saline soil [26], in addition, leaves were alternately arranged providing self-shading in sunny seasons. Under water logging stress, however, soil 02 deprivation might have induced leaf shedding in C. procera due to hormonal disorder and limited energy $[17,23]$.

Galal, et al. [39], have revealed that C. procera thrived well from mid-summer up until the cold season, well represented by high size variation, however, starting spring, the population size showed declined values, they also illustrated that the plant did not produce any seeds during the period from December to March, and that the population structure exhibited high stability under the stress of urban areas.
On the other hand, Farahat, et al. [18], found that C. procera has high plasticity in its morphological and reproductive traits, in which it had continuous flowering for 8 months, with a peak in April and May, that helped in reproductive success of the species, however, the flowering season declines in both very high and low temperatures. According to Sen\&Chatterji [40], seeds couldn't neither germinate at elevated temperatures nor exhibit any dormancy, they even couldn't remain viable for long time, as it was proven by experiment that twoyear-old seeds have lost viability. Eventually, Sen \& Chatterji [39] mentioned that fruit set got enhanced during long hours of sunlight and warmer climate.

Calotropis procera primarily reproduces by seeds [14], the pollen of C. procera is green and somewhat sticky [41], it transfers through cross-pollination by insects, particularly by species such as the monarch butterfly (Danaus plexippus), which uses C. procera as a host plant for various stages of its life cycle [23]. In Egypt, Xylocopa leucothorax males (exclusively) are the main pollinators while a Scoliid wasp is a facultative one [42]. It may receive more visits form pollinators and because of possessing larger flowering stalks it may disperse its seeds more efficiently [43]. Calotropis seeds have a silky pappus that helps to spread by wind, animal, and may be transported on long distances in flood waters [13]. Additionally, it reproduces by vegetative propagation through half stumps, as well as through stem, root suckers and cuttings.

The biological features of Calotropis procera is considered common among invasive plants, such as fast growth and dissemination, high seed production efficiently dispersed by the wind, non-specialized pollination system and high tolerance to poor soils $[44,45]$. It has been declared as an invasive species in Australia where control strategies suggested to remove the tree mechanically with its deep tap root and lateral roots to prevent suckering, furthermore, extensive competition with tall weeds or brushes especially grass might be an efficient way to weaken Calotropis and prevent seed germination, meanwhile, chemical control is advisable for larger Calotropis colonies [13].

Studying the population dynamics and demography of Calotropis procera in Egypt proposed that it is an efficiently performed species and had many plastic phenological, morphological, and reproductive attributes that enable it to show stable persistence under urban habitats conditions, colonize, and invade new ecosystems 


\section{Journal of Ecology \& Natural Resources}

[26,36]. Meanwhile, Brazilian experimental studies have proved its ability to tolerate specific edaphic conditions and hence suggested that it has the potential to invade such habitats $[46,47]$.

\section{Allelopathy of Calotropis procera}

Calotropis procera has allelopathic properties including germination inhibition, plumule and radicle growth reduction. A study aimed to examine the allelopathic potential of Calotropis species on seed germination and seedling growth of Acacia ehrenbergiana, Acacia gerrardii and Acacia tortilis [48], according to their study, the aqueous leaf extracts of Calotropis procera (Aiton) inhibited the seed germination, reduced the seedlings growth, biomass yield and biomass allocation in Acacia species. Besides, different concentrations of C. procera leaf extract had an allelopathic effect on the seed germination of barley (Hordeum vulgare L.), wheat (Triticum aestivum L.), cucumber (Cucumis sativus L.), fenugreek (Trigonella foenum-graecum L.), Alssana (Senna occidentalis L.), tomato (Lycopersicon esculentum Mill.), and eggplant (Solanum melongena L.), showing that, the final germination percentage decreased with increasing leaf extract concentration [49,50]. In addition, Yasin, et al. [51] suggested that the delay in seed germination and the reduction in germination index might reflect the presence of water-soluble inhibitors in C. procera extract, they added that It has widespread and persistent occurrence near barley, oat, rice, sorghum, maize, cotton, sugarcane and especially wheat crop fields, which suggests some adverse effects on these crops through allelopathic interactions. Lastly, allelochemicals present in leaves and stems of C. procera strongly inhibited the germination, seedling growth, fresh and dry biomass of Pennisetum americanum (L.) Leeke and Setaria italica (L.) [52].

\section{Medicinal Importance}

Members of the family Asclepiadaceae secrete milk-like latex that is known traditionally to heal wounds and stop bleeding of fresh cuts [21]. Therefore, Shivaprasad, et al. [53] have tested the scientific validity of this knowledge on four plant species to find that the latex exhibited significant abilities of both blood coagulation and thinning, meaning that the latex contains thrombin like enzymes responsible for clot formation and plasmin like action dissolving it.

Members of the family are also known for treating heart failure since they are rich in cardiac glycosides $[8,9]$. Cardiac glycosides are cardioactive compounds belonging to triterpenoids class of compounds, helps in cases of heart failure by increasing heart contraction strength [54]. Moustafa, et al. [55] have studied the cardiac glycoside effect extracted from the aerial parts of Calotropis procera on several muscles, along with some flavonoids and saponins, they indicated a direct action of the extract on the myocardium, as it increased heart beats and heart contractions, moreover, the compound has increased the motility of smooth muscles as mentioned by Brian, et al. 1985 [53], and on the other hand it had a relaxing effect on the contracted skeletal muscles. Those effects were attributed to the glycosides actions on neural tissue which influence the mechanical and electrical activities of the heart improving vascular resistance [56]. Further studies on cardiac glycosides have also proven anticancer properties, in (2014), Ibrahim et al., have tested the methanolic extract of the root barks of Calotropis procera on lung and prostate cancer cell lines showing remarkable effects compared to the positive control Cisplatin. Besides, Nalini, et al. [57], have confirmed the anticancer properties of Calotropis procera, stating that it acts as an antiglioblastoma against LN-18 cancer cells, they declared that it has potential application and can be incorporated in developing anticancer drug.

Kazeem, et al. (2016) [58], have evaluated the antidiabetic characters of C. procera leaf extract, it revealed an inhibitory effect of carbohydrate hydrolyzing enzymes, $\alpha$-amylase and $\alpha$-glucosidase. Similarly, AbdAlrheam \& Shehri (2015)[59], have successfully used leaf extract as an antidiabetic agent on male albino rates, they also recorded significant decrease in levels of serum cholesterol and triglycerides, which probably an effect of saponin content that has potential effect in the treatment of hypercholesterolaemia by interfering with intestinal absorption of cholesterol [60].

On the other hand, Calotropis procera was found to be highly toxic when introduced to mice food, resulting in high abortion rates [61]. In addition, Ahmed, et al. [62], have assessed the toxic effect of latex and ethanolic leaf extract of Calotropis procera, on the heart and testis of male albino rats, proving high toxicity and recommending the use of C. procera as rodent control.

\section{Calotropis procera as Pesticide}

Studies have determined that some botanical compounds such as alkaloids, nicotine, anabasin and lupitin in the extracts of Calotropis procera latex produced high mortality against mosquito larvae, which make it very efficient in the control of several mosquito species [63-65,10]. Additionally, the plant was discovered to be 


\section{Journal of Ecology \& Natural Resources}

highly toxic to the white garden terrestrial snail Thepa pisana, by the effect of uscharin that was extracted from the latex [7].

\section{Calotropis procera as Renewable Energy Source}

Erdman \& Erdman [11], suggested that hexane extraction of Calotropis procera could be used as a substitute for petroleum or petrochemical feedstocks, they claimed that C. procera yields high-density fluid, rich in hydrocarbon. In their study, the ratio of carbon and hydrogen in the extraction were similar to crude oil and the heat value content was comparable to crude oil, fuel oil and gasoline. Besides, Barbosa, et al. [12] have implied the high concentrations of seeds oil and fatty acids from $\mathrm{C}$. procera in different localities in Brazil, they suggested that oil content and total biosynthesis of saturated fatty acids have been increasing with the increased temperature and drought, and finally concluded that C. procera has potential as biodiesel feedstock.

\section{Molecular Studies}

Not too many molecular studies have dealt with Calotropis procera, in El-Bakry, et al. [66], have studied the genetic variation of $\mathrm{C}$. procera in six different phytogeographic regions in Egypt, the study showed high polymorphism among the tested populations in which, Aswan population had the highest polymorphism of all and hence the most diverse gene pool, the six sampled localities where clustered into three distinct groups; Aswan, Feran valley and the remaining four localities, New Valley, Cairo-Suez road, Nuweibaa, and Arish, the study also revealed that highest similarity was between the populations of Cairo-Suez road and Nuweibaa, while Feran population exhibited the furthest distance.

El-Bakry, et al. [67], investigated the phytochemical polymorphism among Calotropis procera populations collected from the same six localities of the previous study, there was a significant difference in primary metabolites; carbohydrates and proteins, and secondary metabolites; cardiac glycosides and flavonoids, among different populations. The maximum values of carbohydrates and cardiac glycosides were recorded in the population from Wadi Feran, while the minimum values were recorded from Cairo-Suez road and New Valley. Meanwhile, proteins had its highest concentration in Aswan and the lowest from Arish. On the other hand, flavonoids attained their maximum concentration in $\mathrm{Al}-$ Arish and their minimum in Nuweibaa. El-Bakry et al. added that, proteins had decreased with the increase in soil chlorides, calcium, magnesium and potassium, while flavonoids concentrations had increased directly with the increase of chlorides, sodium and potassium in soil.

Furthermore, three Calotropis genotypes from three locations; El Maghara, Shalateen and Saint Cathrine, were investigated using two molecular techniques; RAPD-PCR and ISSR, resulting in two cluster dendrogram, one included El Maghara and Shalateen genotypes, while the other was Saint Cathrine, which indicated high similarity between El Maghara and Shalateen populations and Saint Cathrine of least similarity [27].

\section{Discussion and Interpretation}

Several studies have suggested the invasive potential of Calotropis procera which depends on the different traits it possess that shows fast growth rate, effective dispersion, high adaptation to wide range of environmental conditions or - quoting Ismail (1992)-"it has no Achilles heel". However, the studies didn't detect any actual alteration of ecosystem or competition over space or resources with any other species so far. According to the previously mentioned studies, it was observed that Calotropis procera only exhibited invasive behavior in habitats where it was introduced into such as south and central America and Australia, those habitats were characterized by elevated rates of precipitations and high nutrient content in their soils in comparison to the Egyptian arid habitats where $C$. procera is originally a native plant. On top of that, seeds of $C$. procera can hardly germinate in extreme temperatures which is the case in Egypt's hot and cold seasons, however, Brazil and Australia have no such extremes meaning that seed germination can be successful all year round probably resulting in exponential increase in populations. To sum up, the invasion danger of $C$. procera is highly dependent on environmental conditions of different habitats, the extremely arid habitat in Egypt doesn't encourage the plant to grow widely as well as extreme temperature in both summer and winter inhibits seed germination for a period of time until conditions are suitable over again and hence limiting the growth and dispersal of the populations.

Calotropis procera populations in Egypt are highly polymorphic which indicates highly divers genetic pool that can hardly be threatened, furthermore, molecular studies suggested that there is a correlation between the edaphic conditions of a population and the nature of its metabolites since they differed in different soils [66]. Further study of this feature can be beneficial in 
identifying which population to be targeted in medicinal industries and which in hydrocarbon synthesis.

Regardless to its allelopathic effect to some crops, Calotropis procera has several ecologic roles, its ability to accumulate several elements from different soils serves as natural phytoremediation [68-71], can possibly improve the quality of soil and hence rehabilitating abandoned and exhausted lands. In Egypt, there has been respective number of C. procera populations in intensive industrial regions such as Helwan south of Cairo [18,26] it's one of the most polluted areas in Egypt, consequently the presence of C. procera could act as a natural refiner for air and soil. As was mentioned by Lottermoser [14], C. procera had the ability to uptake high concentrations of Uranium in its tissues when grew in an abandoned mining site in Australia not to mention, vast number of heavy metals and natural elements were detected in its tissues that correlated highly to soil content. Another ecologic role, Calotropis procera is known to attract about 80 animal species, which range from casual visitors to those dependent on the plant for completing their life cycle [72], which provide highly productive ecosystem to abandoned lands. Furthermore, its appearance can be used as an indicator of overgrazing and poor soil and hence drive the attention to manage the stressed lands.

In an overpopulating developing country such as Egypt, having C. procera is a bless, it is famous for its various medicinal and phytochemical properties along with hydrocarbon content that can be used as an alternative clean source of energy, it also can be used as a safe pesticide and rodent control without leaving harmful chemical traces. Calotropis procera presents such a rich natural resource that must be utilized industrially, it provides ecofriendly solutions to our pollution, energy limitation and habitat degradation problems.

\section{References}

1. Abdel Azim NS, Shams KA, Shahat AA, El Missiry MM, Ismail SI, et al. (2011) Egyptian Herbal Drug Industry: Challenges and Future Prospects. Research Journal of Medicinal Plant 5(2): 136-144.

2. UNESCO (1998) Promotion of ethnopotany and sustainable use of plant resources in Africa. pp: 60 .

3. Farnsworth NR, Soejarto DD (1991) Global importance of medicinal plants. In: Akerele 0 , Heywood V, Synge H. (eds) The Conservation of Medicinal Plants. Cambridge University Press, Cambridge, UK 25-51.
4. Schippmann U, Leaman DJ, Cunningham AB (2002) Impact of Cultivation and Gathering of Medicinal Plants on Biodiversity: Global Trends and Issues. Inter-Department Working Group on Biology Diversity for Food and Agriculture, FAO, Rome, Italy.

5. Pankaj O (2003) Doomar or gular (Ficus glomerata) as medicinal herbs in Chattishgarh, India.

6. Boulos L (1999) Flora of Egypt. Vol. I (AzollaceaeOxalidaceae). Al Hadara Publishing, Cairo, Egypt.

7. Hussein HI, Kamel A, Abou-zeid M, EL-Sebae AH, Saleh MA (1994) Uscharin, The Most Potent Molluscicidal Compound Tested Against Land Snails. Journal of Chemical Ecology 20(1): 135-140.

8. Barrett B, Kieffer D (2001) Medicinal plants, science and health care. J Herb Spice Med Plant 8(2-3): 1-36.

9. EAPCCT (2008) Abstracts of the XXVIII International Congress of the European Association of Poison Centers and Clinical Toxicologists. Clin Toxicol 46(5): 351-421.

10. Shahi M, Hanafi Bojd AA, Iranshahi M, Vatandoost $H$, Hanafi Bojd MY (2010) Larvicidal efficacy of latex and extract of Calotropis procera (Gentianales: Asclepiadaceae) against Culex quinquefasciatus and Anopheles stephensi (Diptera: Culicidae). J Vector Borne Dis 47(3): 185-188.

11. Erdman MD, Erdman BA (1981) Calotropis procera as a source of plant hydrocarbons. Econ Bot 35(4): 467-472.

12. Barbosa MO, Almeida-Cortez J, da Silva SI, Oliveira AM (2014) Seed Oil Content and Fatty Acid Composition from Different Populations of Calotropis procera (Aiton) W. T. Aiton (Apocynaceae). J Am Oil Chem Soc 91(8): 14331441.

13. Parsons WT, Cuthbertson EG (2001) Noxious weeds of Australia, Seconds edn. Csiro Publishing, Melborn 712 pages.

14. Lottermoser BG (2011) Colonisation of the rehabilitated Mary Kathleen uranium mine site (Australia) by Calotropis procera: toxicity risk to grazing animals. J Geochem Explor 111: 39-46. 
15. El Hadidi MN (2000) Geomorphology, climate and phytogeographical affinities. In: El Hadidi MN (ed) Flora aegyptiaca, vol 1. The Palm Press, Cairo, pp 145.

16. El Wahab RHA, Zaghloul MS, Kamel WM, Moustafa AA (2008) Diversity and distribution of medicinal plants in North Sinai. Egypt Afr J Environ Sci Technol 2: 157-171.

17. Ibrahim AH (2013) Tolerance and avoidance responses to salinity and water stresses in Calotropis procera and Suaeda aegyptiaca. Turk J Agric 37(3): 352-360.

18. Farahat E, Galal TG, El Midany M, Hassan LM (2015) Effect of urban habitat heterogeneity on functional traits plasticity of the invasive species Calotropis procera (Aiton) W.T. Aiton. Rendiconti Lincei 26(2): 193-201.

19. Morcelle SR, Caffini NO, Priolo N (2004) Proteolytic properties of Funastrum clausum latex. Fitoterapia 75(5): 480-493.

20. Vitelli JAE, Madigan BB, Wilkinson PC, Haaren $\mathrm{P}$ (2008) Calotrope (Calotropis procera) control. The angeland Journal 30(3): 339-348.

21. Boulos L (2000) Flora of Egypt, Vol. 2 GeraniaceaeBoraginaceae. Al Hadara Publishing, Cairo, Egypt.

22. Akhtar N, Malik A, Ali SN, Kazmit SU (1992) Proceragenin, an antibacterial cardenolide from Calotropis procera. Phytochem 31(8): 2821-2824.

23. Orwa C, Mutua A, Kindt R, Jamnadass R, Antony S (2009) Agroforestry database: a tree reference and selection guide version 4.0. World Agroforestry Center, Kenya.

24. Parrotta JA (2001) Healing plants of Peninsular India. CAB International, Wallingford, UK and New York.

25. Rahman MA, Wilcock CC (1991) A taxonomic revision of Calotropis (Asclepiadaceae). Nord J Bot, 11(3): 301-308.

26. Farahat E, Galal TG, El-Midany M, Hassan LM (2015) Phenology, biomass and reproductive characteristics of Calotropis procera (Aiton) WT Aiton in South Cairo, Egypt. Rend. Fis. Acc. Lincei 27(2): 197-204.
27. Bekhit, MMM, El Shawaf, IIS, Hassan, et al. (2008) Genetic distances between three Ushaar (Calotropis procera (Ait) f.) genotypes as measured by RAPD and ISSR techniques. The fourth conference of sustainability.

28. Little EL Jr, Woodbury RO, Wadsworth FH (1974) Trees of Puerto Rico and the Virgin Islands, vol. 2. Agriculture handbook 449. U.S. Department of agriculture, Washington1: 024.

29. Murti Y, Yogi B, Pathak D (2010) Pharmacognostic standardization of leaves of Calotropis procera (Ait.) R. Br. (Asclepiadaceae). Int J Ayur Res 1(1): 14-17.

30. Sharma R, Thakur GS, Sanodiya BS, Savita A, Pandey M, et al. (2012) Therapeutic Potential of Calotropis procera: a giant milkweed. J Pharm Bio Sci 4(2): 4257.

31. Kleinschmidt HE, Johnson RW (1977) Weeds of Queensland. Queensland department of primary industries, Australia 147p.

32. Howards RA (1989) Flora of the Lesser Antilles, Leeward and Windward Islands. Dicotyledoneae. Part 3. Arnold Arboretum, Harvard University, Jamaica Plain 6: 658.

33. El Midany M (2014) Population dynamic of Calotropis procera in Cairo province. M.Sc. Thesis. Helwan University, Cairo, Egypt.

34. D Souza RJ, Varun M, Masih J, Paul MS (2010) Identification of Calotropis procera L. as a potential phytoaccumulator of heavy metals from contaminated soils in urban north central India. J Hazard Mater 184(1-3): 457-464.

35. Francis JK (2003) Calotropis procera. U.S. Department of agriculture, fore service, international institute of tropical forestry, Puerto Rico.

36. Galal TM, Farahat EA, El-Midany MM, Hassan LM (2015) Nutrients and heavy metals accumulation by the giant milkweed Calotropis procera (Aiton) W.T. Aiton in urbanized areas, Egypt. Rend Lincei 27(2): 241-250.

37. McLaurin WJ, Kays SJ (1993) Substantial leaf shedding - a consistent phenomenon among high yielding sweet potato cultivars. Hort Sci 28(8): 826827. 
38. Hasselquist NJ, Allen MF, Santiago LS (2010) Water relations of evergreen and drought-deciduous trees along a seasonally dry tropical forest chronosequence. Oecologia 164(4): 881-890.

39. Galal TM, Farahat EA, El-Midany MM, Hassan LM (2015) Demography and size structure of the giant milkweed shrub Calotropis procera (Aiton) W.T. Aiton. Rend Lincei 27(2): 341-349.

40. Sen, DN, Chatterji UN (1965) Ecological studies on Calotropis procera (AIT.) RBr. Australian Arid Zone Res Conf C 25-26.

41. Hassan LM, Galal TM, Farahat E, El-Midany M (2015) The biology of Calotropis procera (Aiton) W.T. Trees 29(2): 311-320.

42. Schremmer F (1972) Der Stechsaugru ssel, der Nektarraub, das Pollensammeln undder Blutenbesuch der Holzbienen (Xylocopa) (Hymenoptera, Apidae). Z Morph Tiere 72: 263-294

43. Crick JC, JP Grim (1987) Morphological plasticity and mineral nutrient capture in two herbaceous species of contrasted ecology. New Phytologist 107(2): 403-414.

44. Barreto RW, Evans HC, Pomella AWV (1999) Fungal pathogens of Calotropis procera (rubber bush), with two new records from Brazil. Australasian Plant Pathology 28(2): 126-130.

45. Melo MM, Vaz FA, Gonc alves LC, Saturnino HM (2001) Estudo fitoquímico da Calotropis procera Ait., sua utilizac,ão na alimentac,ão de caprinos: efeitos clı́nicos e bioquímicos séricos. Rev Bras Sau'de Prod An 2: 15-20.

46. Oliveira S, Negreiros D, Fernandes GW, Barbosa N, Rocha R, et al. (2009) Seedling growth of the invader Calotropis procera in ironstone rupestrian field and seasonally dry forest soils. Neotropical Biology and Conservation 4(2): 69-76.

47. Frosi G, Oliveira MT, Almeida-Cortez J, Santos MJ (2013) Ecophysiological performance of Calotropis procera: an exotic and evergreen species in Caatinga, Brazilian semi-arid. Acta Physiol Plant 35(2): 335-344.

48. Shetta N, Alshahrani TS, Aref IM, Nasser R (2017) Allelopathic potential of Calotropis procera and
Ecucalyptus species on germination and growth of some timber trees. Allelopathy Journal 40(1): 81-94.

49. Al-Zahrani HS, Al-Robai SA (2007) Allelopathic effect of Calotropis procera leaves extract on seed germination of some plants. J king Abdullah U 19: 115-126.

50. Ghasemi S, Ghasemi M, Moradi N, Shamili AM (2012) Effect of Calotropis procera leaf extract on seed germination of some plants. JOHP 2(1): 27-32.

51. Yasin M, Safdar ME, Iqbal Z, Ali A, Jabran K, Tanveer A (2012) Phytotoxic effects of Calotropis procera extract on germination and seedling vogor of wheat. Pak J Weed Sci Res 18: 379-392.

52. Samreen U, Hussain F, Sher Z (2009) Allelopathic potential of Calotropis procera (Ait.) Ait. Pak J Pl Sci 15(1): 7-14.

53. Shivaprasad HV, Riyaz M, Kumurar RV, Dharmappa KK, Tarannum S, et al. (2009) Cysteine proteases from the Asclepiadaceae plants latex exhibited thrombin and plasmin like activities. J Thromb Thrombolysis 2 (3): 304-308.

54. Brian FH, Thomas-Bigger J, Goodman G (1985) The pharmacological basis of therapeutics, 7th Edition, Macmillan Publishing Company, New York: 716718.

55. Moustafa AMY, Ahmed SH, Nabil ZI, Hussein AA, Omran MA (2010) Extraction and phytochemical investigation of Calotropis procera: Effect of plant extracts on the activity of diverse muscles. Pharmaceutical Biology 48(10): 1080-1190.

56. Olaleye MT (2007) Cytotoxicity and antibacterial activity of methanolic extract of Hibiscus sabdariffa. Journal of Medicinal Plants Research 1(1): 009-013.

57. Nalini S, Nandini S, Suresh GS, Melo JS, Neelagund SE, et al. (2016) An electrochemical perspective assay for anticancer activity of Calotropis procera against glioblastoma cell line (LN-18) using Carbon nanotubes- graphene nano- conglomerate as a podium. Adv Mater Lett 7(12): 1003-1009.

58. Kazeem MI, Mayaki AM, Ogungbe BF, Ojekale AB (2016) In-vitro Studies on Calotropis procera Leaf Extracts as Inhibitors of Key Enzymes Linked to Diabetes Mellitus. Iran J Pharm Res 15: 37-44. 
59. Abd Alrheam A, Shehri Z (2015) Ethanopharmacological study of the aqueous, chloroform, ethanol leaves extracts and latex of Calotropisprocera in diabetic rats. Biomedical Research and Therapy 2(11): 396-401.

60. Malinow MR, Mclaughin P, Kohler GO, Livingstone AL (1977) Alfalfa saponins: A family of substances potentially usefull for treatment of hypercholesterolaemia. Clin Res 25: 974-979.

61. Faye B (1985) Contribution à l'étude de la toxicité de Calotropis procera Effet d'une alimentation à base de Calotropis procera sur la mortalité embryonnaire met néonatale chez la souris de laboratoire Rev. Elev. Méd. vét. Pays trop 38 (1): 72 75.

62. Ahmed OM, Fahim HI, Boules MW, Ahmed HY (2016) Cardiac and testicular toxicity effects of the latex and ethanolic leaf extract of Calotropis procera on male albino rats in comparison to abamectin. SpringerPlus 5(1): 1644.

63. Morsy TA, Rahem MA, Allam KA (2001) Control of Musca domestica third instar larvae by the latex of Calotropis procera (Family: Asclepiadaceae). J Egyptian Soc Parasitol 31(1): 107-110.

64. Singhi M, Joshi V, Sharma RC, Sharma K (2004) Ovipositioning behaviour of Aedes aegypti in different concentrations of latex of Calotropis procera: studies on refractory behaviour and its sustenance across gonotrophic cycles.

65. Ramos MV, Bandeira GP, de Freitas CDT, Nogueira NAP, Alencar NMN, et al. (2006) Latex constituents from Calotropis procera (R.Br.) display toxicity upon egg hatching and larvae of Aedes aegypti (Linn). Mem Instit Oswaldo Cru 101(5): 503-510.

66. El Bakry AA, Hammad IA, Ghazi SM, Rafat FA (2014) Polymorphism in Calotropis procera: variation of metabolites in populations from different phytogeographical regions of Egypt. Rendiconti Lincei 25(4): 461-469.

67. El Bakry AA, Hammad IA, Rafat FA (2014) Polymorphism in Calotropis procera: preliminary genetic variation in plants from different phytogeographical regions of Egypt. Rendiconti Lincei 25(4): 471-477.
68. Baker AJM (1981) Accumulators and excluders strategies in the response of plants to heavy metals. Journal of Plant Nutrition 3(1-4): 643-654.

69. Baker AJM, Brooks RR (1989) Terrestrial higher plants which hyperaccumulate chemical elements - a review of their distribution, ecology and phytochemistry. Biorecovery 1:81-126.

70. Brooks RR (1998) Biogeochemistry and hyperaccumulators. In: Brooks, R.R. (Ed.), Plants that Hyperaccumulate Heavy Metals. CAB International, Oxford: 95-118.

71. Krämer U (2010) Metal hyperaccumulation in plants. Annu Rev Plant Biol 61: 517-534.

72. Amritphale D, Sharma S (2007) Learning foodchain with Calotropis procera. Resonance 12(1): 67-75.

73. Akinloye AK, Abatan MO, Alaka 00, Oke BO (2002) Histomorphometric and Histopathological Studies on the Effect of Calotropis procera (giant milkweed) on the male reproductive organs of wistar rats. African Journal of Biomedical. Research 5: 57-61.

74. Ali T, Ali SI (1989) Pollination biology of Calotropis procera subsp. hamiltonii (Asclepiadaceae). Phyton (Horn) 29: 175-188.

75. Al Yahya MA, Al Meshal IA, Mossa JS, Al Badr AA, Tarig M (1990) Saudi plants: a phytochemical and biological approach. KSU press, Riyadh 31-34.

76. CABI (2005) Forestry compendium. CAB Publishing, Wallingford.

77. Ibrahim SRM, Mohamed GA, Shaalad LA, Moreno L, Banulsf Y (2014) Proceraside A, a new cardiac glycoside from the root barks of Calotropis procera with in vitro anticancer effects. Nat Prod Res 28(17): 1322-1327.

78. Ismail AMA (1992) Physiological Growth Analysis of The Life-History of Calotropis procera (AlT.) AlT. F Qatar Univ Sci J 12: 94-100.

79. Kassas M (1955) Rainfall and vegetation belts in arid NE Africa. Plant Ecology. Proc. of the Montpellier Symp, UNESCO 49-77.

80. Madhyastha M, Shenoy S, Ramachandra VH, Desai R, Tilak A, et al. (2017) A study of effect of acute and chronic administration of aqueous extract of 


\section{Journal of Ecology \& Natural Resources}

Calotropis procera leaves on maximal electroshock induced seizures in rats. Int J Basic Clin Pharmacol 6(1): 1-4.

81. Malinow MR, Mclaughin P, Kohler GO, Livingstone AL (1977) Prevention of elevated cholesterolaemia in monkeys. Steroids 29(1): 105-110.
82. Tahar B (2010) Effects of water stress on root growth, water use efficiency, leaf area and chlorophyll content in the desert shrub Calotropis procera. J. Int. Environmental Application and science 5(2): 124.

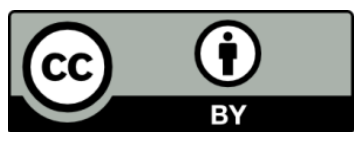

